\title{
DYNAMIC AND MULTISCALE ANALYSIS OF VEGETATION COVER: MEXICALI, B.C. MEXICO
}

\author{
A. ARIAS-VALLEJO \& R. ROJAS-CALDELAS \\ Architecture and Design Faculty, Autonomous University of Baja California
}

\begin{abstract}
Urban expansion patterns and the rapid, excessive growth of housing development have created a negative impact in city's vegetation or urban green areas (UGA). Traditional urban planning does not adopt a holistic approach at an urban-region level, nor considers ecological and environmental functions of UGA, for example, changes in structure, function and dynamics. Throughout the world a deficit in vegetation cover is present, finding UGA below the minimum range established to meet urban standards and to achieve the quality of life. The objective of this paper is to propose a methodology to analyse and evaluate the structure, dynamics and function of UGA at the urban-region level in time. This paper developed a regional and urban cover vegetation analysis for the period between 2004 and 2013 within city and peri-urban area of Mexicali, B.C. Mexico. It was conducted through land use and land cover analysis, and NDVI; using database of Mexicali urban development master plan, SPOT-6 and LandsatL8 images, as well as ARGIS and MapInfo software. The results showed discontinuity in vegetation cover in the rural-urban transition; four zones within the city that have vegetation cover with a significant size, but their conditions are not in the most optimal state; poor UGA structure without connection between its elements; homogeneous urban fabric which highlights the constructed space and bare soil over the areas with vegetation; and that the arboreal vegetation occurs in lower quantity and quality compared to grass cover.

Keywords: ecological planning, landscape, scales, urban green areas, urban planning, urban-region, vegetation cover.
\end{abstract}

\section{INTRODUCTION}

Nowadays, the care and protection of the environment have become a constant issue in urban and regional planning of the countries. This concern has been increasing due to the urban expansion patterns as a result of the excessive growth and sprawl of housing development, which has also caused a negative impact on land cover and land use change over productive, forest and natural reserve areas for the conservation of natural resources that surround cities, the reduction of biodiversity, the increments on temperature and air pollutants and, the degradation, fragmentation and loss of connectivity of urban green areas. However, urban planning and management authorities of such places have ignored the current problems and planning models are too far from considering the provision of urban green areas through a holistic approach including its ecological and environmental functions [1-4].

The relevance of the study of urban green areas lies on the opportunity to examine its quantity, quality, distribution, connectivity and roles played in the city, as well as their interaction with surrounding areas, as mentioned by several authors $[1,5,6]$. In addition, urban green areas have become a core element to improve population well-being through its functions $[7,8]$. 
Planning of urban green areas has been discussed from different perspectives, or from different scales such as regional, urban or site. Nevertheless, nowadays they have been treated independently and without considering their inter-relationship $[9,10]$. On one hand, projects of regional character or macro scale regularly with ecological or environmental approach, are seeking to show if landscape have been affected by the rapid and uncontrolled urbanization as well as changes in land-use patterns [3,4,11-18]. On the other hand, projects at urban or meso scale are focused to highlight particular problems in specific areas [1,2,19-24]. Nonetheless, these studies leave out the relationship between urban green areas with natural and productive areas.

Due to the mentioned scenario, the following questions were stated: 1) Why planning of urban green areas is not considered from a holistic approach in the city of Mexicali, B. C., Mexico?, and 2) Why urban development planning does not consider an ecological approach to define land suitability for green areas through the analysis of structure and function of green areas through time and scale in the city of Mexicali, B. C., Mexico?

According to what is shown in Urban Development Program Mexicali 2025 (PDUCP 2025) [25], the city of Mexicali, has a deficit in the coverage of green areas of $1.31 \mathrm{~km}^{2}$, providing the city with just $2 \mathrm{~m}^{2} /$ person. Such number is below the minimum value determined in Mexico [25,26], which correspond to $5 \mathrm{~m}^{2} /$ person. Moreover, according to de Gante and Rodriguez [27] the green areas of this city are below of what the World Health Organization (WHO) establishes as the ideal range to achieve the quality of life of a city, which must be between $10 \mathrm{~m}^{2}$ and $15 \mathrm{~m}^{2}$ of green area per inhabitant. Additionally, the Ecological Management Plan of the Municipality of Mexicali [28] indicates that the growth at east, southeast and south of the city has led to the loss of agricultural areas and natural reserves, declining biodiversity, increasing temperature and air pollutants. No matter of the situation, the authorities have not taken into account the current problems, and they continue ignoring the ecological functions of urban green areas for their planning, management and supply from a holistic approach.

Therefore, this work aims to propose a methodology that facilitates the analysis and assessment of urban green areas in the city of Mexicali, B.C. Mexico from the transition between two scales, regional and urban, in the period 2004-2013, based on the approach of the ecological planning and landscape ecology principles [9,10,14,29-34] for the selection and adaptation of those elements necessary to achieve the management, care, protection and preservation of green areas as a priority factor in promoting sustainability in the city of Mexicali, $\mathrm{BC}$, Mexico through a holistic planning of green areas.

\section{METHODOLOGY}

\subsection{Study area}

The study area is the urban area of the city of Mexicali, B.C. Mexico, and $7 \mathrm{~km}$ buffer to the east, south and west of the periphery of the city. The city of Mexicali is the capital of the municipality of the same name and the capital of the state of Baja California. It is located in an arid area in northeastern Mexico in the physiographic province of the Sonoran Desert (latitude $32^{\circ} 40^{\prime} \mathrm{N}$ and longitude $115^{\circ} 28^{\prime} \mathrm{W}$ ); its territory area is of $148.9 \mathrm{~km}^{2}$ and the total population in the urban area is of 689.775 inhabitants [35,36]. Mexicali is located on the international border with the US; it is bordered by two agricultural valleys: to the north with Imperial Valley, California, USA and to the south with Mexicali Valley, Mexico (located in the lower Colorado River basin, particularly in the delta plain); to the east is an 
area of sand dunes; to the west is a strip of mountains that spread out from north to south called: El Centinela, Sierra Cucapah and El Mayor [37, 38]. The soils of the urban area and its surroundings are considered primarily of expansive clay type with low permeability, and its terrain is relatively flat [39]. The climate is dry arid (BWh), has low rainfall. The average annual temperature is $22^{\circ} \mathrm{C}$, presenting minimum temperatures up to $2^{\circ} \mathrm{C}$ between December to March and maximum temperatures up to $48^{\circ} \mathrm{C}$ between May and September. The prevailing winds are northwest-southeast from November to April and southeastnorthwest from May to October. The natural vegetation is the Xeric scrub, represented by species of Larrea tridentata, parvifolio scrub subinerme, Ambrosia dumosa and Ambrosia deltoid, which mainly occupy the plains, alluvial fans and hillsides [25].

\subsection{Data sources and method}

To perform this analysis and assessment, it was proposed the analysis of land covers structure and function at a macro (regional or periphery area) and meso (urban) scale, adapting the methods and tools used by La-Greca et al. [4] at macro scale $(1: 250,000)$ and by Salvati and Zitti [3] at meso scale (1:20,000). For both scales, it was identified and analysed the land uses and cover, as well as cover change patterns in a period of 2004-2013. To perform these analyses, information from PDUCP 2025 [25], Mexicali Cadastral provided by Landeros [40], and medium resolution satellite images from year 2013 [41, 42] were used (Table 1).

\subsubsection{Land-use analysis at regional and urban scale}

To perform the land-use analysis at the regional scale or at periphery area, two types of land uses were identified: Urban and agricultural. In addition to these groups, at urban land five subgroups were identified: villages, roads, railroad tracks, drains and canals; and at agricultural land, two subgroups were identified: land with crops or vegetation and uncultivated land or in preparation.

Table 1: Information of satellite images. Own elaboration based on $[42,43]$.

\begin{tabular}{|c|c|c|c|c|c|}
\hline \multicolumn{4}{|c|}{ Scene/Year 2013} & \multicolumn{2}{|c|}{ Scene/Year 2013} \\
\hline \multirow{12}{*}{ 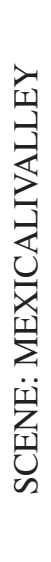 } & Type & LC8 OLIS/TIRS & \multirow{12}{*}{ 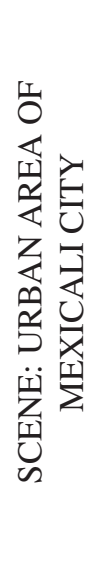 } & Type & SPOT 6 \\
\hline & Name & LC80390372O13167 & & Name & 201304131S09526_ \\
\hline & & LGN00 & & & SEN_816018101 \\
\hline & Path/Row & $39 / 37$ & & Path/Row & $39 / 37$ \\
\hline & Date & June 16 & & Date & April 13 \\
\hline & Bands & $11(\mathrm{RGB}+\mathrm{SIR}+\mathrm{TIRS})$ & & Bands & 4 (RGB+MR) \\
\hline & Multi spectral & $30 \mathrm{~m}$ & & Multispectral & $6 \mathrm{~m}$ \\
\hline & Panchromatic & $15 \mathrm{~m}$ & & Panchromatic & $2.5 \mathrm{~m}$ \\
\hline & $\%$ & 0.34 & & Combined & $1.5 \mathrm{~m}$ \\
\hline & Cloudiness & & & Resolution & \\
\hline & Quality & 9 & & Ortho-rectifíed & Yes \\
\hline & Ortho-rectified & Yes & & Scale & $1: 50,000$ \\
\hline
\end{tabular}


For the land-use analysis at the urban scale, information provided by the PDUCP 2025 [25] was reviewed. It shows that for 2004, the city had 13 different urban land uses, divided into two groups: 1) occupied land and 2) available land to be occupied. First, the land uses at urban occupied area were: housing, roads, industry, trade and services, urban corridor, urban facilities, mixed use, infrastructure, storage and services, maintenance, and green areas (including only public spaces and those within the urban recreation facilities [26]). Second, the land uses at urban available land to be occupied, presents the following: vacant urbanized and non-urbanized, and rustic land. Therefore, this study considered the following land uses as most important: 1) housing, due to the present vegetation in their private gardens, 2) green areas such as urban parks, and 3) barren lands.

\subsubsection{Land cover analysis at regional and urban scale}

Land cover analysis was conducted with a Vegetation Index (VI) that can be defined as the calculated parameter from the reflectivity values at different wavelengths that is intended to extract the information related to vegetation, minimizing the influence of disturbances derived from soil or weather conditions that occur at the time satellite photo is taken, it was also needed the normalized difference vegetation index analysis (NDVI) [43]. To perform the land cover analysis, the use of software IDRISI Selva V.17 and ArcMap 10 was necessary. Before the land cover analysis is accomplished, it is necessary to carry out the treatment of satellite images for both areas: periphery area (regional scale) and the urban area.

2.2.2.1 Treatment of satellite images. At the regional scale, a LC8 Landsat satellite photo (scene) was used. The satellite image treatment is performed with IDRISI Selva V.17 software. The original size of the scene was larger than the study area therefore a scene trimming was conducted to delimitate the study area (Fig. 1). The elements that could generate confusion in the land cover classification were eliminated as stated by Mather [44]: human settlements, roads, railroad tracks, drains and canals. Giving as a result three types of land cover: 1) irrigated vegetation, 2) recent vegetation and 3) barren farm land (Fig. 2).

At city or urban scale, Spot 6 image was used. Treatment to the image was done using software ArcMap 10. Land cover or vegetation analysis was carried out through supervised

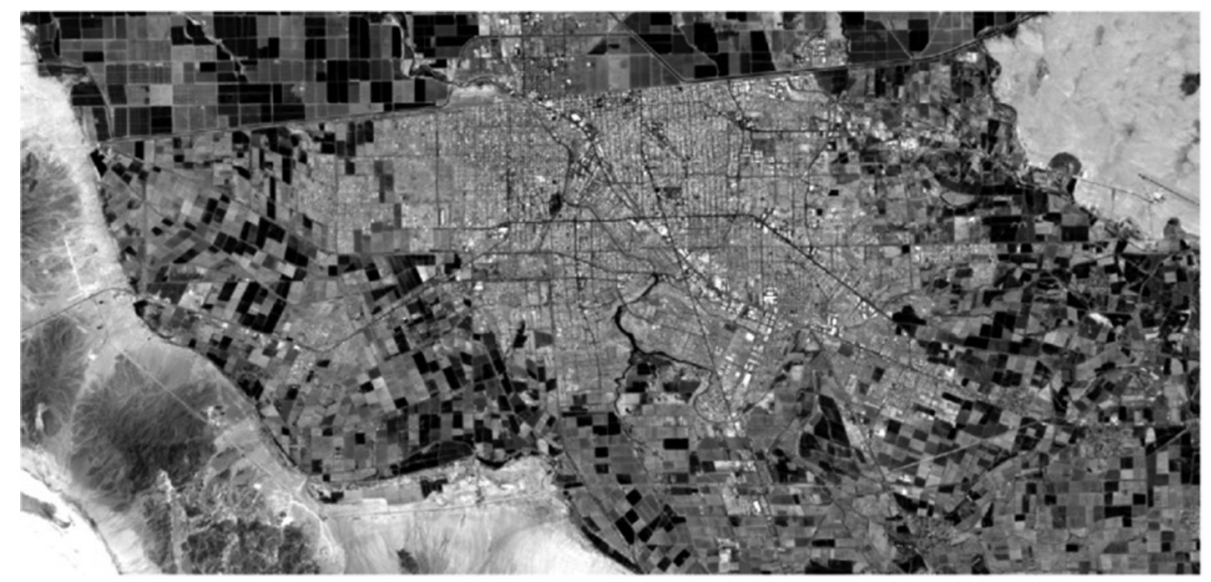

Figure 1: LC8 Landsat image defining the study area. Own elaboration based on satellite image [42]. 


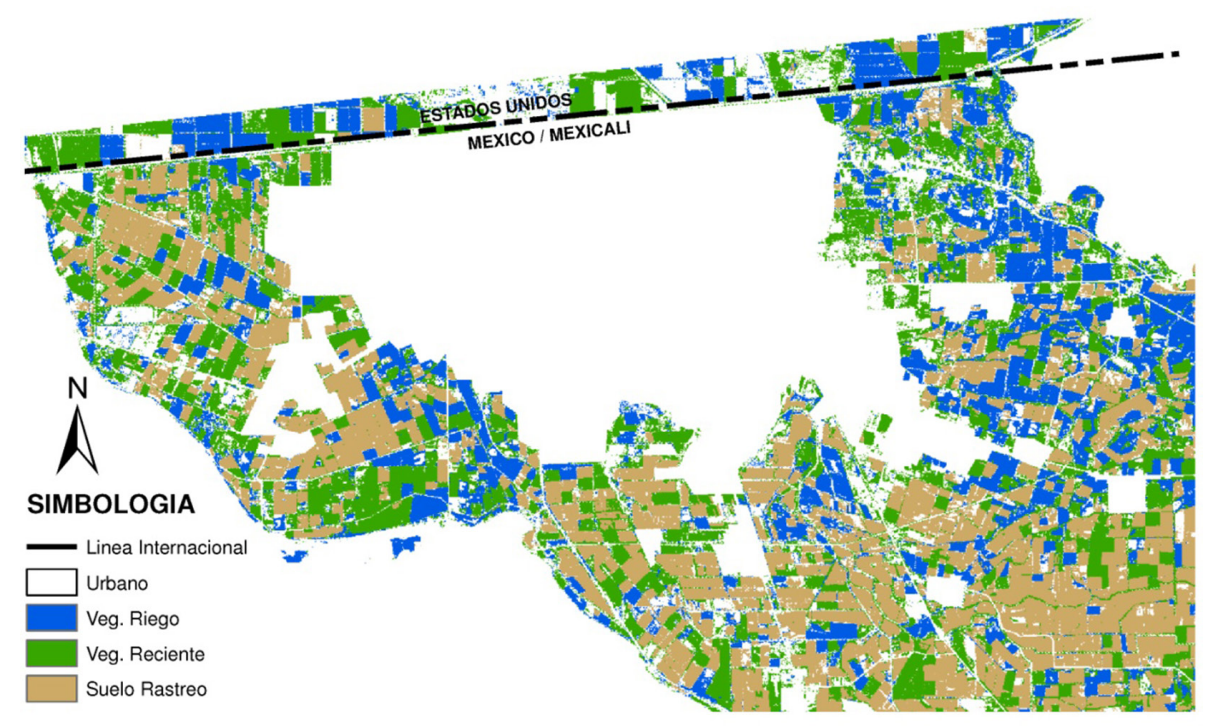

Figure 2: Image showing the classification of land cover. Own elaboration based on satellite image [42].

classification method due to prior knowledge of the study area, either by field visits, research articles in the area, and site images analysis [44]. To distinguish and interpret more easily, the type of vegetation cover in the area, as well as to generate training sites a false color image was necessary, therefore, a combination of bands was needed: 413 RGB (Fig. 3) as per Chuvieco [45]. Once this classification is done, eight types of land cover in the urban area were obtained (color shown in parentheses): 1) Structures with dark color roofing (light red), 2) Structures with light color roofing (white), 3) Vegetation/grass (light green), 4) Vegetation/ trees (dark green), 5) Vegetation/Agriculture (medium green), 6) Roads (gray), 7) barren urban land (cream), and 8) Water Bodies (blue) (Fig. 4).

The splicing of land cover at both scales, periphery and urban area, gives as a result an image that shows 12 land covers in the area of study (color shown in parentheses): 1) vegetation/grass (yellow), 2) vegetation/trees (light green), 3) agricultural vegetation (medium green), 4) barren urban land (light brown), 5) dark color roofs (light red), 6) light color roofs (silver), 7) roads (dark gray), 8) water bodies (blue), 9) urban land (gray), 10) irrigated vegetation (bluish green), 11) recent vegetation (bright medium green), and 12) barren farm land (cream) (Fig. 5).

2.2.2.2 Normalized Difference Vegetation Index Analysis (NDVI). The NDVI was applied only to the vegetation cover within the urban area, because the land use in the periphery is primarily for the agriculture. To perform this analysis, it was required the use of software ArcMap 10. The ESRI [46] indicates that this process is used to represent the vegetation greenness (values between -1.0 and 1.0).

\section{RESULTS}

The information obtained and updated point out that the urban area presented a growth of $3.58 \%$ over its territorial extension from 20,633.52 hectares in 2004 to $21,372.07$ hectares of 


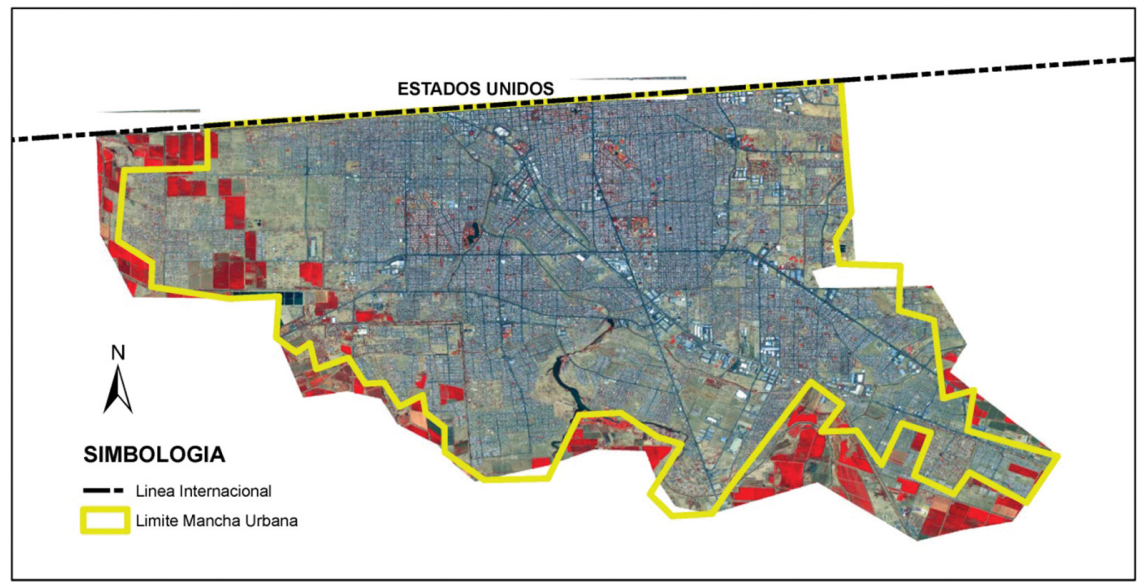

Figure 3: Image on false color. Own elaboration based on satellite image [43].

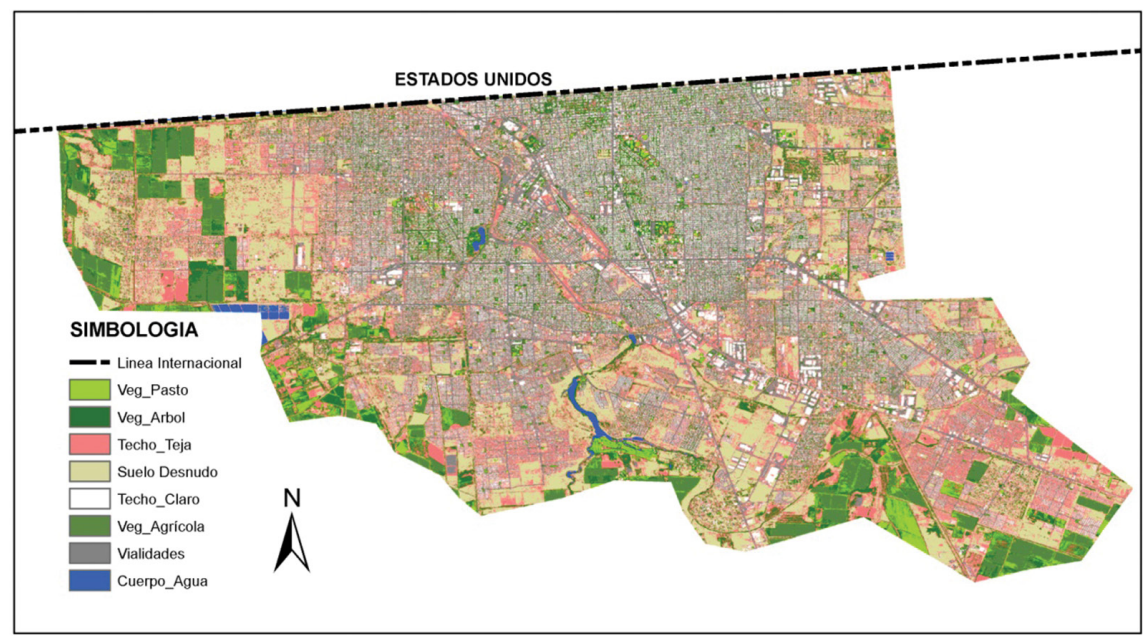

Figure 4: Land cover map in the city. Own elaboration based on satellite image [43].

land developed in 2013 (Fig 6). From the total of such surface, in year 2013, the $53.98 \%$ of land use correspond to housing developments covering 11,538.58 ha showing an increase of $36.52 \%$ compared to what was shown in 2004 . Green areas occupy $1.27 \%$ of the urban area covering 271.32 ha decreasing $9.24 \%$ compared to what was in 2004. Finally, barren urban land represent $26.50 \%$ of land use covering a total surface of 5,663.82 ha which represent an increase of almost $21 \%$ compared to what was in 2014 (Table 2).

Therefore, it can be mentioned that although the housing land use has been increasing, this increment has not been reflected with vegetation. Vegetation is the only land use presenting coverage deficit over urban area.

Based on the information obtained from supervised classification, it is important to mention that: first, on the periphery of Mexicali city, due to changing land use from agricultural 


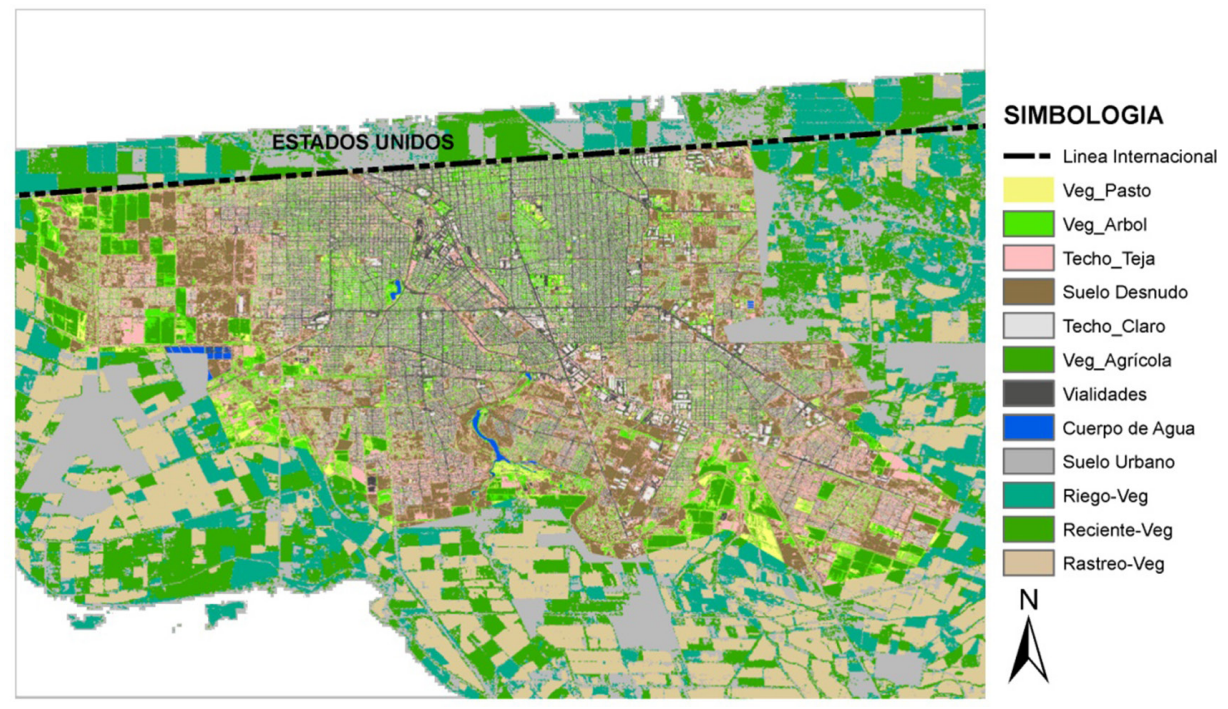

Figure 5: Land cover map in the city and valley of Mexicali. Own elaboration based on satellite images $[42,43]$.

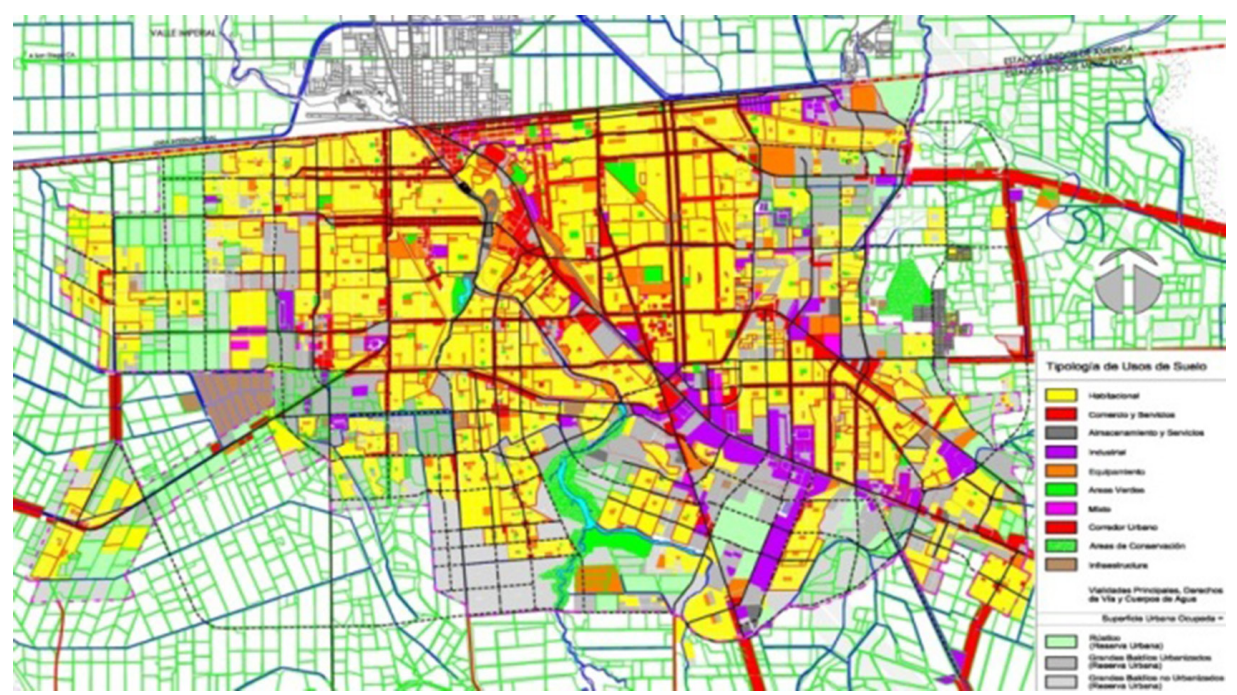

Figure 6: Land use in the urban area of city of Mexicali. Based on PDUCP 2025 [25].

to urban, a land cover discontinuity is present in the transition from rural to urban area (Fig. 7); second, vegetation cover in the urban area of Mexicali, based on the NDVI image (Fig. 8), shows how the urban fabric is very homogeneous, highlighting buildings and roadways, i.e., it can be considered as a city where the gray of the buildings prevail. It does not show any pattern of connectivity. The city present clusters on certain areas where vegetation is more abundant than in the rest of the city. 
Table 2: Comparative chart of land use and green areas in Mexicali. Own elaboration based on PDUCP 2025 [25] and Landeros [41].

\begin{tabular}{llllll}
\hline \multicolumn{5}{c}{ 2004 URBAN } & \multicolumn{2}{l}{ 2013 } \\
LAND USE & AREA (has) & $2004 \%$ & AREA (has) & 2013 \% & $\begin{array}{l}\text { Coverage } \% \\
\text { 2004-2013 }\end{array}$ \\
\hline Housing & $8,451.94$ & 40.96 & 1L53S.ÍS & 53.98 & +36.52 \\
Urban Green Area & 298.93 & 1.45 & 271.32 & 1.27 & -9.24 \\
Barren land & $4,682.91$ & 22.70 & $5,663.82$ & 26.50 & +20.95 \\
Other & $7,199.74$ & 34.89 & $3,898.35$ & 18.25 & -54.15 \\
TOTAL Urban & $20,633.52$ & 100 & $21,372.07$ & 100 & +3.58 \\
Area & & & & & \\
\hline
\end{tabular}

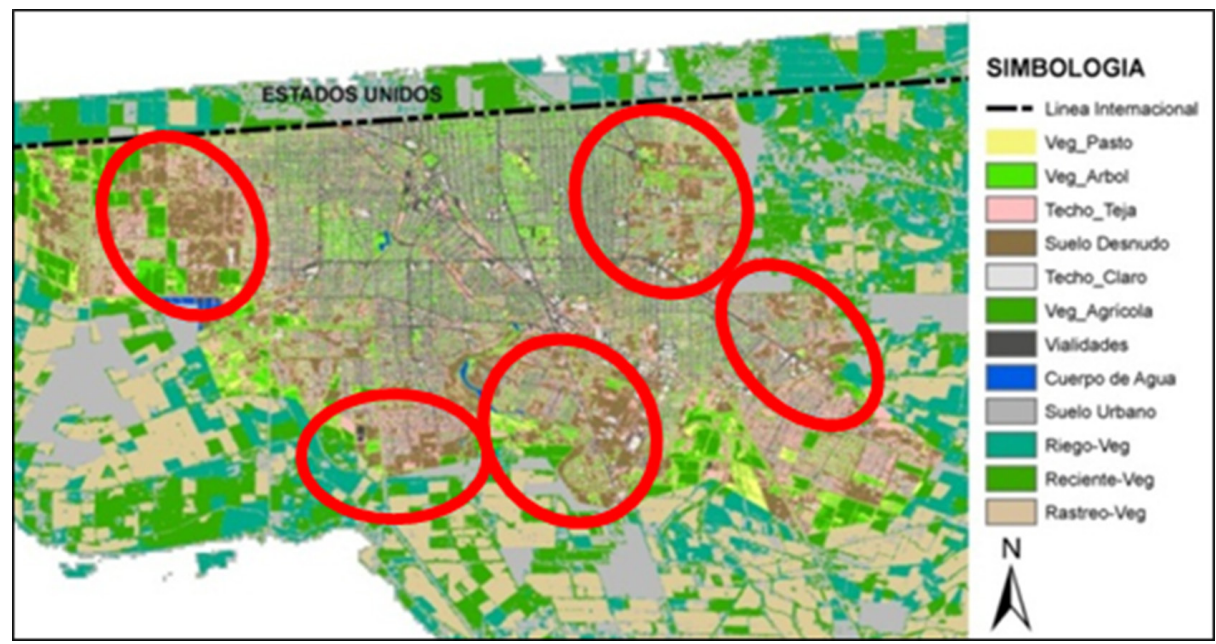

Figure 7: Circles show discontinuity in vegetation cover. Own elaboration based on satellite images $[42,43]$.

There was found four vegetation clusters located at north, west and at core area of the city. (Fig. 9). Furthermore, it stands out that grass is the representative element with larger volume in land cover. It also shows that trees have no relevance in this city's land cover.

\section{DISCUSSIONS}

This study allows highlighting that the city of Mexicali, BC has poor structure in its green areas with limited connection between its elements resulting in a disjointed ecological function of its green areas. When planning of green areas is managed from a particular or single approach through a single scale without considering time, it leaves out the possibility of linking, highlight and propose solutions to the problem that has been presented at the transition of land use and land cover changes from urban into rural areas with obsolete productive soil throughout the time, that is the case it was tried to prevent with this study contrary to what it was done by La-Greca et al. [4] and Salvati and Zitti [3]. 


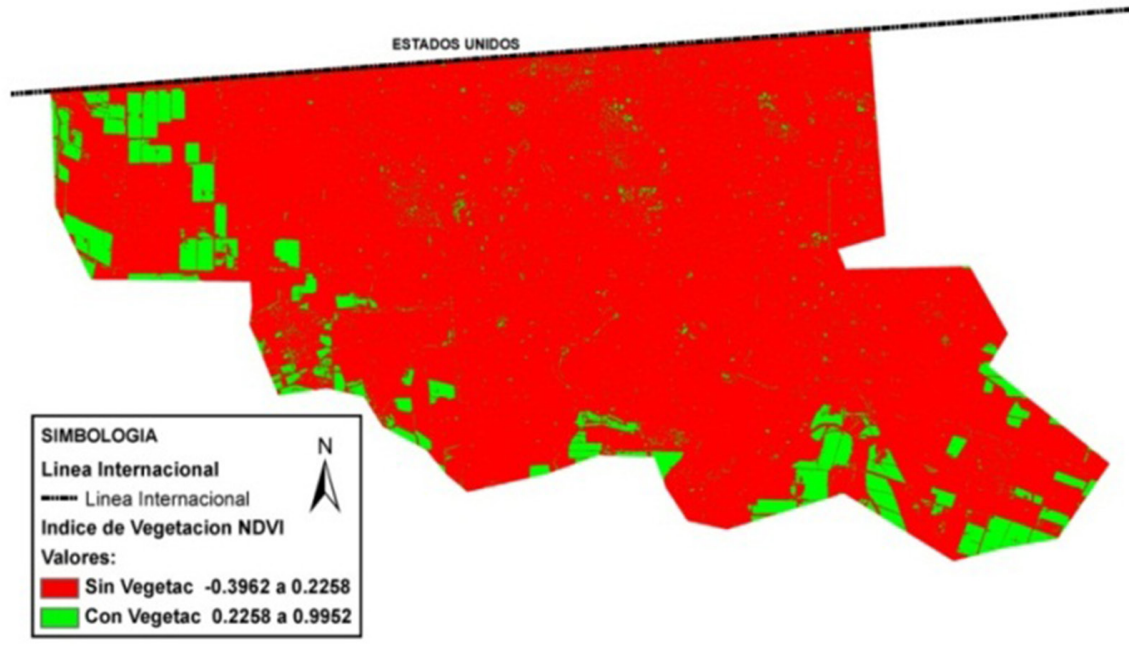

Figure 8: NDVI map in Mexicali. Own elaboration based on satellite image [43].

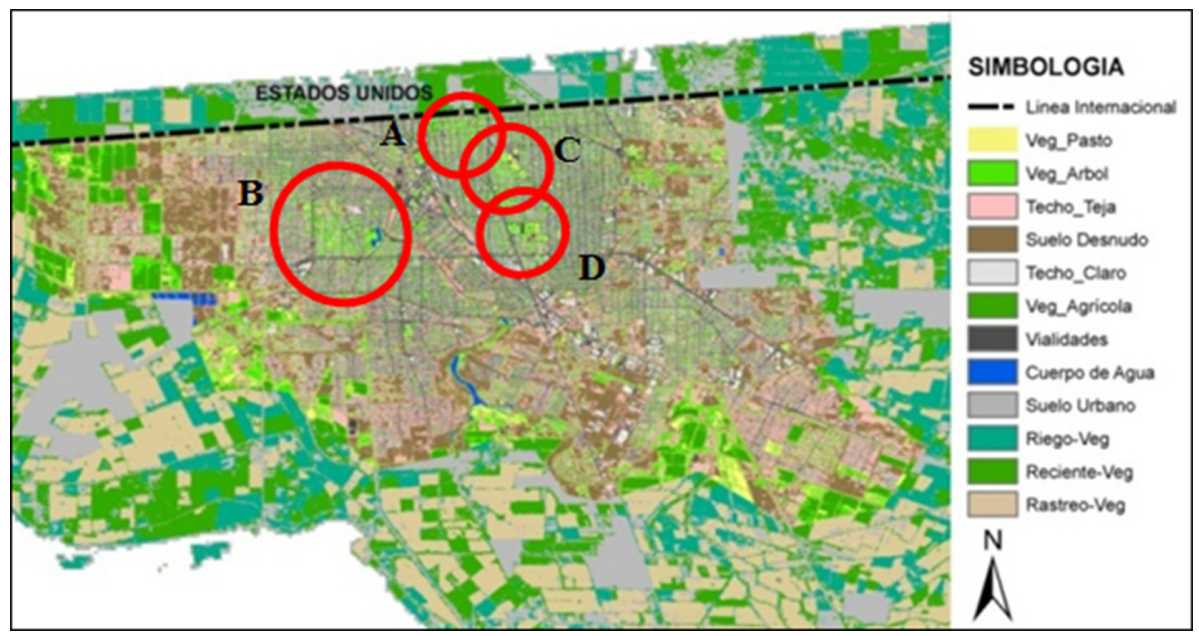

Figure 9: Circles in red represent areas of vegetation concentrated as clusters in the city. Own elaboration base on satellite images $[42,43]$.

It should be pointed out that performing an analysis with a methodology that covers time and scale change of cover patterns in vegetation allows a comprehensive analysis to propose strategies to solve problems presented in: 1) changes of land-use periphery areas due to the growth of the urban area; 2) identify areas and patterns of major loss or decrease in vegetation cover in the urban-rural transition; 3 ) the excessive growth of new residential projects, located particularly in periphery areas, which do not consider the green areas as an integrating element in the planning of these spaces. 


\section{REFERENCES}

[1] Duc-Uy, P. \& Nakagoshi, N., Application of land suitability analysis and landscape ecology to urban greenspace planning in Hanoi, Vietnam. Urban Forestry \& Urban Greening, 7, pp. 25-40, 2008.

http://dx.doi.org/10.1016/j.ufug.2007.09.002

[2] Zhou, X. \& Wang, ,Spatial-temporal dynamics of urban green space in response to rapid urbanization and greening policies. Landscape and Urban Planning, 100, pp. 268-277, 2011.

http://dx.doi.org/10.1016/j.landurbplan.2010.12.013

[3] Salvati, L. \& Zitti, M., Monitoring vegetation and land use quality along the rural-urban gradient in a Mediterranean region. Applied Geography, 32, pp. 896-903, 2012.

http://dx.doi.org/10.1016/j.apgeog.2011.09.002

[4] La-Greca, P., La Rosa, D., Martinico, F. \& Privitera, R., Agricultural and green infraestructures: The role of non-urbanized areas for eco-sustainable planning in a metropolitan region. Environmental Pollution, 159, pp. 2193-2202, 2011. http://dx.doi.org/10.1016/j.envpol.2010.11.017

[5] Peña, C.A., Metodología para la planificación de áreas verdes urbanas: el caso de Mexicali, Baja California, UABC: México, 2011.

[6] Reyes, S. \& Figueroa, I.M., Distribucion, superficie y accesibilidad de las áreas verdes en Santiago de Chile. EURE, 36, pp. 89-110, 2010. http://dx.doi.org/10.4067/S0250-71612010000300004

[7] Peña, C.A., Las plantas en el diseño del paisaje. Funciones arquitectónicas y estéticas, Universidad Autnónoma de Baja California: Mexicali, B.C, 1998.

[8] Salvador, P., La planificación verde en las ciudades, 1ra edn., Editorial Gustavo Gili, S. A: Barcelona, 2003.

[9] Selman, P., Environmental Planning: The Conservation and Development of Biophysical Resources, 2nd edn., SAGE Publications Ltd: London, 2000.

[10] Steiner, F., Living Landscape : An Ecological Approach to Landscape Planning, 2nd edn., Island Press: Washington, DC, 2008.

[11] Aguilera, F., Valenzuela, L. \& Botequilha-Leitão, A., Landscape metrics in the analysis of urban land use patterns: a case study in a Spanish metropolitan area. Landscape and Urban Planning, 99, pp. 226-238, 2011.

[12] Deng, JS., Wang, K., Hong, Y. \& Qi, JG., Spatio-temporal dynamics and evolution of land use change and landscape pattern in response to rapid urbanization. Landscape and Urban Planning, 92, pp. 187-198, 2009.

http://dx.doi.org/10.1016/j.landurbplan.2009.05.001

[13] Echeverría, C., Newton, A., Nahuelhual, L., Coomes, D. \& Reybenayas, JM., How landscapes change: Integration of spatial patterns and human processes in temperate landscapes of southern Chile. Applied Geography, 32, pp. 822-831, 2012. http://dx.doi.org/10.1016/j.apgeog.2011.08.014

[14] Farina, A., Principles and Methods in Landscape Ecology. Towards a Science of Landscape, Springer: Netherlands, 2006.

[15] Piquer-Rodríguez, M., Kuemmerle, T., Alcaraz-Segura, D., Zurita-Milla, R. \& Cabello, J., Future land use effects on the connectivity of protected area networks in southeastern Spain. Journal for Nature Conservation, 20, pp. 326-336, 2012. http://dx.doi.org/10.1016/j.jnc.2012.07.001

[16] Rodriguez-Galiano, V. \& Chica-Olmo, M., Land cover change analysis of a Mediterranean area in Spain using different sources of data: Multi-seasonal Landsat images, 
land surface temperature, digital terrain models and texture. Applied Geography, 35, pp. 208-218, 2012.

http://dx.doi.org/10.1016/j.apgeog.2012.06.014

[17] Romero-Ruiz, M.H., Flantua, S.G.A., Tansey, K. \& Berrio, J.C., Landscape transformations in savannas of northern South America: Land use/ cover changes since 1987 in the Llanos Orientales of Colombia. Applied Geography, 32, pp. 766-776, 2012.

http://dx.doi.org/10.1016/j.apgeog.2011.08.010

[18] Tang, J., Wang, L. \& Yao, Z., Analyses of urban landscape dynamics using multi-temporal satellite images: A comparison of two petroleum-oriented cities. Landscape and Urban Planning, 87, pp. 269-278, 2008.

http://dx.doi.org/10.1016/j.landurbplan.2008.06.011

[19] Brown, G., Mapping landscape values and development preferences: a method for tourism and residential development planning. International Journal of Tourism Research, 8, pp. 101-113, 2006.

http://dx.doi.org/10.1002/jtr.562

[20] Estoque, R. \& Murayama, Y., Examining the potential impact of land use/cover changes on the ecosystem services of Baguio city, the Philippines: A scenario-based analysis. Applied Geography, 35, pp. 316-326, 2012. http://dx.doi.org/10.1016/j.apgeog.2012.08.006

[21] Hostetler, M., Allen, W. \& Meurk, C., Conserving urban biodiversity? Creating green infrastructure is only the first step. Landscape and Urban Planning, 100, pp. 369-371, 2011.

http://dx.doi.org/10.1016/j.landurbplan.2011.01.011

[22] Mahmoud, A.H.A. \& El-Sayed, M.A., Development of sustainable urban green areas in Egyptian new cities: The case of El-Sadat City. Landscape and Urban Planning, 101, pp. 157-170, 2011.

http://dx.doi.org/10.1016/j.landurbplan.2011.02.008

[23] Wright-Wendel, H., Zarger, R. \& Mihelcic, J., Accessibility and usability: Green space preferences, perceptions, and barriers in a rapidly urbanizing city in Latin America. Landscape and Urban Planning, 107, pp. 272-282, 2012. http://dx.doi.org/10.1016/j.landurbplan.2012.06.003

[24] Zube, E., Simcox, D. \& Friedman, S., Desert riparian landscapes: Values and change, 1981-96. Landscape and Urban Planning, 42, pp. 81-89, 1998. http://dx.doi.org/10.1016/S0169-2046(98)00079-6

[25] POE., Programa de Desarrollo Urbano de Centro de Población Mexicali 2025, in Periodico Oficial del Estado de Baja California, Mexicali, B.C, pp. 3-124, 2007.

[26] SEDESOL., Recreación y Deporte. Sistema Normativo de Equipamiento Urbano. 1999, Recuperado de, available at http://angelsergioasa.files.wordpress.com/2011/06/ sedesol-tomo5-recreacic3b3n-y-deporte.pdf

[27] de Gante, V.H. \& Rodriguez, M., Parques y jardines del municipio de Puebla. Elementos. No. 76, pp. 51-55, 2009.

[28] POE., Plan de Ordenamiento Ecológico del Municipio de Mexicali, in Periodico Oficial del Estado de Baja California, Mexicali, pp. 3-126, 2000.

[29] Odum, E.P, \& Barrett, G.W., Fundamentos de Ecología, 5th edn. International Thomson Editores, S. A. de C. V: Mexico, 2006.

[30] Green, D., Klomp, N., Rimmington, G. \& Sadedin, S., Complexity in Landscape Ecology, 1st edn., Springer-Verlag New York, LLC: New York, 2009. 
[31] Forman, R. \& Godron, M., Landscape Ecology, John Wiley \& Sons, Inc: United States, 1986.

[32] Ndubisi, F., Ecological Planning : A Historical and Comparative Synthesis, The Johns Hopkins University Press: Baltimaore, 2002.

[33] Makhzoumi, J. \& Pungetti, G., Ecological Landscape Design and Planning : The Mediterranean Context, E \& FN Spon, 1999.

[34] Steiner, F., Young, G. \& Zube, E., Ecological planning: retrospect and prospect. Landscape Journal, 7(1), pp. 31-39, 1988.

[35] INEGI. Censo de Población y Vivienda 2010. Principales resultados por localidad (ITER). 20103 de Mayo de 2013], Recuperado de, available at http://www.inegi.org. $\mathrm{mx} /$ sistemas/consulta_resultados/iter2010.aspx ?c=27329\&s=est

[36] Venegas, R.F., El uso de la flora urbana en ciudades con clima árido seco extremoso., in Ciudad, salud y medio ambiente, Universidad Autonoma de Puebla. Programa editorial de la red de investigacion urbana, A.C: Puebla, Pue, pp. 105-116, 2000.

[37] Jordán, F., Baja California, tierra incógnita, Universidad Autónoma de Baja California: Mexicali, B.C, 2005.

[38] Leyva, O., Transición hacia la sustentabilidad del Desarrollo Urbano de la ciudadregión de Mexicali, 1990-2005, Universidad Autónoma de Baja California: Mexiclai, B.C, 2011.

[39] Avilés, A.M., Atlas de Mexicali: un espacio urbano en la estrategia internacional, Universidad Autónoma de Baja California: Mexicali, B.C, 2001.

[40] Landeros, J.G., Base de datos catastrales de la ciudad de Mexicali, B.C. del año 2013, Servicios y Análisis Integrados de Mexicali, S. C: Mexicali, B.C, 2014.

[41] USGS, Landsat L8 OLIS/TIRS in escene LC80390372013167LGN002014, USGS: Sioux Falls.

[42] Apollo-Mapping. SPOT 6 Imagery. 2014; Recuperado de: https://apollomapping.com/

[43] Gilabert, M.A., González-Piqueras, J. \& García-Haro J., Acerca de los Indices de Vegetación, Revista de Teledetección, 1997.

[44] Mather, P., Computer Processing of Remotely-Sensed Images: An Introduction, 3rd edn., John Wiley and Sons, Ltd: England, 2004.

[45] Chuvieco, E., Teledetección ambiental. La observación de la Tierra desde el espacio, Editorial Ariel, 2010.

[46] ESRI., ArcGis Help Library, Environmental Systems Research Institute, Inc.: United States of America, 2014. 